\section{Emerging Innovative Thoughts on Globalization Amidst the Contagion of COVID-19}

\author{
Emerson Abraham Jackson \\ Centre of West African Studies, University of \\ Birmingham, Birmingham, UK \\ Model Building Analysis Section, Research \\ Department, Bank of Sierra Leone, Freetown, \\ Sierra Leone
}

\section{Synonyms}

Integration; Market development; Transmittable

\section{Definition(S)}

The concept of globalization is quite broad, and given its many facets, it can be linked to three main areas, namely, economic, political, and social as outlined in the definitions below:

- According to Shangquan (2000), economic globalization refers to the increasing interdependence of world economies as a result of the growing scale of cross-border trade of commodities and services, flow of international capital, and wide and rapid spread of technologies.

- Political globalization involves transformations in the relations between political processes and territorial states (Ougaard 2004).

- Social globalization, on the other hand, is defined as information flows, personal contacts, and cultural sharing across countries (Cho 2013; original citation in Dreher 2006).

The above definitions provide specific scope with regard to the original definition of globalization as provided by the World Health Organization (Online), which state thus: increased interconnectedness and interdependence of peoples and countries, and it is generally understood to include two inter-related elements: the opening of international borders to increasingly fasts flows of goods, services, finance, people and ideas, and the changes in institutions and policies at national and international levels that facilitate or promote such flows. There is a real focus on interconnectedness, with the possibility for people in the global community to access opportunities through cross-border movements.

Disclaimer: Views expressed in this chapter are those of the author and do not reflect any of the named institutions for which he is associated. 


\section{Introduction}

The concept of globalization first emerged in English dictionary around the 1940s, with a broad focus in addressing economic and political issues. In contemporary time, the discourse of globalization is now channelled in the direction of speed, particularly in the area of technological innovation and its consequences on social, political, and economic life (Estrada and Arturo 2020; Griffith and Marion 2020; Kinnvall 2004). Claims of the historical commencement of globalization have been dated as early as in 1492 (Christopher Columbus in search of America) and 1498 (Vasco da Gama's run in Africa in a bid to snatch monopoly rent from the Arabs and Venetian spice traders). Empirical study produced by O'Rourke and Williams (2000) spelt the dichotomy of the economic relevance of nineteenth Century globalization boom in comparison with the acclaimed exploration of Christopher Columbus and Vasco da Gama. O'Rourke and Williams' (2000) study provides the connection of globalization impact on concerns relating to factor prices, commodity prices, and endowments worldwide.

As specified above, globalization, though not completely rosy given the experiences from Transatlantic slave trade to industrial revolution period in the USA (in addition, the nineteenthcentury effort in Latin America and East Asia), has gone a long way in bringing people together, typically epitomized by an easy mobility of people and resources across continental borders (O'Rourke 2019). With the expansion of trade liberalization measures in Southeast Asian economies (notably Singapore, Indonesia, and the Philippines), many of these economies were also able to take advantage of the move towards globalization, given the independence of governments to invest highly in human resource potential, with the added benefits of cheap factor of production (Bassino and Williams 2017; O'Rourke and Williams 2017). Such venture is quite admirable, and the benefits have been enjoyed through liberalization policies, which come in the form of technology transfer and innovative mind-sets through creation of better opportunities in relation to jobs and higher growth prospects as linked with the SDG8 agenda (Perraton 2019; Milberg and Winkler 2013). The transfer of technology channelled through means like foreign direct investments (FDI) has made it more beneficial for countries with high level of human resource capacity to take advantage of opportunities by utilizing rent-seeking to develop domestic industrial base for the utilization of expanded growth capacity as witnessed in many of the Asian Tiger economies, notably Japan, Malaysia, Indonesia, and Singapore (Jackson and Jabbie 2020).

The objective of this chapter is dedicated to explore emerging thoughts on how best to cultivate innovative approach to the concept of globalization, given the recent challenge that COVID-19 has brought to the global economy. This is crystalized through the collapse and re-engineering of vital structures (e.g., closure of educational establishments, businesses, with central banks adopting swift measures to support institutions, etc.) as the pandemic continues to manifest itself across continental borders. The experience of the 2014-2016 Ebola epidemic in Sierra Leone and its neighboring countries, for example, made it possible for global investment models in epidemic preparedness and resource allocation to be utilized through creative innovation in drug research and the utilization of techno-managerial creativity as control measures equally too, countries around the world and, more specifically, across Africa have engaged in preparedness for the widespread impact of COVID19 , given the experience of globalization associated with China-Africa interaction (Leach 2020).

Despite the ongoing concerns of COVID-19, there is no doubt in relation to the benefits that globalization has brought to the world economy to highlight a few, the development of modern economies in the Asian bloc spearheaded through transfer of technologies that took advantage of cheap factors of production (viz., labor) and among others, welfare gains, which so far have been manifested through improved prospects relating to job creation and equality in gender participation across the globe (Danaeefard and Abbasi 2011; Cho 2013). 


\section{Theoretical Underpinnings of Globalization}

Theoretically, the concept of globalization was initially classified under three main themes, namely, economic, political, and social (Shangquan 2000; Cho 2013). As time progresses, there was a need to address wider categories of its remit, which is hereby grouped under eight headings as emphatically exemplified below (PooJo Online):

- Theory of Liberalism - this is construed as a market-led process of globalization, which requires human beings to seek for greater economic welfare and political liberty. Such innate desire of human beings to explore their freedom has fructify itself as seen through advances in technological progress pertaining to transportation, communication, and the firming up of appropriate legal and institutional setup to promote market-led liberalization across continental borders. Contrary to the liberalist view of globalization, there are schools of thought which believe strongly that the First World War was on account of the forces of liberalism as supported by the HeckscherOhlin model of trade (Rowe 2005).

- Political Realism Theory - this is based on the reality of state powers, more so in pursuit of national interest and conflict between states the greatest of this is to do with the dominance of one state or group over the other - for example, the G7, which currently influences the state of international rule, while at the same time containing conflict between other states (PooJo Online). This has its benefit given the need to address reality concerned with political integration, more so in facilitating benefits pertaining to trade liberalization and movement of people across regions as seen in the European Union and other regional institutions such as the African Union (reference to Wivel 2004).

- Marxist Theory of Globalization - this conceptual theory is modelled on Marxist mode of production, which seeks to eradicate social exploitation through unjust distribution and freedom as masterminded in capitalism (PooJo
Online). Marxist rejection of liberalist and political realists' explanation of globalization is based on capitalists inherent tendency to exploit surplus accumulation of capital, with the ulterior motive of maximizing profits - such approach is machinated through the establishment of legal institutional framework, which also instigate classicism in society. One way forward in addressing Marxist objective is for economies to utilize their own designated means of self-capacity, considered more suited to individual economy's developmental pace, in achievement of self-sufficiency as promoted in the case with Import Substitution Industrialization (Jackson and Jabbie 2020). An extension of Marxist philosophy is rooted in neoMarxism, which actually examines the significance of the underclass to resist the globalization of capitalism through support from new socialist movements, along the line of consumer advocates, environmentalists, peace activists, and racism and women's movement in a bid to addressing equality.

- Theory of Constructivism - this is associated with the construct of people's view of the social world, also linked with symbolism, language, images, and interpretation (PooJo Online). This is based on the dynamic conscience of human beings - such is the case with the current pace of production level and governance. The pursuit of human being is modelled on continuous conversation and symbolic exchanges, which makes it possible for constructs about the world to be developed. In this regard, the informed notion pertaining to the epistemological and ontological domain of social geography is making it possible for people to be engaged, both mentally and physically with occurrences in the global community (Held and McGrew 2007; Jackson 2016). This really explains the main focus of social constructivist view, by paying particular attention to international actors (more so the utilization of advanced technologies and their contribution to the acceleration of economic globalization), quality of anarchy and state actors (Mozaffari 2002). One of the main issues of this theory is its neglect for issues connected with structural inequalities and 
power hierarchy in the domain of social relations, which to some extent can be explained for the early neglect of COVID-19 by the capitalists, who are purportedly considered to be the godfather of globalization.

- Postmodern Theory of Globalization - this is epitomized by its rationalist feature, which puts emphasis on the empirical world and subordination of nature to human control (PooJo Online). There is an overwhelming emphasis on economic growth, technological innovation, and bureaucratic organizations - the carved creative destruction concept as initiated by Schumpeter is thought to fit well into the characterization of postmodern theory of globalization, given its emphasis on entrepreneurial ability and innovation (Jackson 2020a). There is a tendency for this form of knowledge to manifest authoritarianism and cultural imperialism, which therefore diminishes all other forms of knowledge exploration pertaining to the theoretical concept of globalization. The postmodern view of globalization makes it possible for human critical mind-set to go beyond all of the aforementioned theories, with the possibility of exposing social or exploitative conditions (notably market forces, mergers, financial crisis, drone strikes, deposed migrants, and stigmatized Muslims) that are certainly in support of the conventional form of globalization (Chatterjee 2019).

- Feminist Theory of Globalization - this is based on the emphasis of social construction on masculinity and femininity. In this regard, it is obvious that women are more at risk of being marginalized than their male counterpart, while remaining silent about pertinent issues around global discourses (Jackson and Jackson 2020; PooJo Online). This is also a radical form of globalization, which seeks to address women's concerns pertaining to the internationalization of social, political, and economic affair of things, while it is perceived that women's influences are considered negligible in the world of opportunities (Chatterjee 2019). The persistence of women to be vocal about discriminatory issues and other forms of marginalization is making it possible for their efforts to be subsumed very well into the general discourses of globalization.

- Globalization Theory of Transformationalism - this is construed as the speed of transformation in the spatial organization of social relations and transactions (more so in tandem with multiple competencies - see Saffa and Jabbie 2020), which normally operate through transcontinental or inter-regional flows and other forms of networked activities (PooJo Online). In this, there is a connection between the hyperglobalization approach, which typically meant that people everywhere are being subjected to the underlying notion of events in the global marketplace. In this vein, one will expect the presence of multinational enterprises (MNE) and intergovernmental organizations (IGOs) to be seen as key players, with their motive of maximizing profits through exploitative means of cheap factors of production, while ignoring their role in embracing corporate social responsibility of the host communities (Jackson and Jackson 2017). In view of its application to reality, Murat and Isaac (2019) conducted a study to assess the effect of globalization on the performance of Small and Medium Enterprises (SMEs) in Nigeria. The study, which utilizes the ex post facto covered a scoping period of 32 years (19862018); the outcome suggests that Nigerian government should encourage import and export of SME products and service across border, with little or no restriction on their products and services as a way of encouraging their expansion and growth in Nigeria.

- Globalization Theory of Eclecticism - this theory is broad-based as it does not hold rigidly to a single paradigm. Therefore in this regard, one will consider it to be the model approach to address concerns and developments revolving around the broad concept of globalization, given the presence of accommodative means to draw upon multiple theories or styles as a way of gaining deeper insight into contemporary discourses. The determination of capitalists to amass wealth, which means exposure to fierce competition over competitors, is a subject of market forces that requires the adoption 
of a competitive approach to wide-ranging paradigms. In order words, given that the capitalist motive is hinged on expanding markets, while also moving assets across national boundaries through exposure of technological innovation, it is absolutely necessary that consideration is given to a combination of relevant theories (PooJo Online).

The above explanatory theories provide the underlying basis on which the concept of globalization is modelled, with the ulterior motive of facilitating interaction and integration among people, businesses, and governments across the world. Despite emphasis being laid on economic outcomes, the entirety of theoretical underpinnings as detailed above and in particular the eclectic approach makes it possible for areas concerning ecological, political, and social discourses to be addressed as part of the wider motive of integrating societies. Whichever way the perceived benefits may be constructed from, more so in terms of economic growth, expansion, and development of human creativity, the underlying motive is manifested through creative destruction as manifested through innovation technologies (Jackson 2020a). There are still critics or antagonists who think the process is detrimental to societal well-being, be it at global or local level. Such antagonistic views could be linked to issues revolving around the natural sustainability of long-term or expansion of economies and the persistent inequalities or environmental concerns arising from capitalists' predatory or hegemonic influences associated with the process of globalization (Jackson 2020a; Jackson and Jackson 2017; Overland 2016; Vujakovic 2010).

\section{Recent Challenges Blighting Prospect for Globalization}

Historically, globalization seems to have gone through series of transformation and not only as witnessed with the emergence of COVID-19. Notably, one could point to the era of the 1930s, which manifested itself with issues concerning deglobalization that calls for increase in tariffs, with widespread imposition of import and export quotas (O'Rourke 2019). Moving on from the great recession and more lately in 2018, the USA, under the premiership of President Donald Trump also pursued an action contrary to the effort of globalization by calling for some form of tariff restrictions on its trading partner, more so China (O’Rourke 2018).

Applaud for globalization as the way forward in addressing growth prospect in the world economy has brought with it new concerns on the emergence of COVID-19 (Kidman and Chang 2020). This time, the forecast of economic downturn (4\% decline as presented by Tim Clayton, 23 March, 2020) was not even a possible consideration when one contemplate on COVID-19 as an exogenous factor (epitomized by the attribute of an error term - Warburton and Jackson 2020) in a typical econometric model as exemplified in Yilmazkuday's (2020) empirical analysis. On a day-to-day basis, one will be more inclined to focus attention on the possibility of a crash in the housing market and the usual turbulence of stock market announcements, associated with supply-side driven shock, normally linked with crude oil and other forms of disturbances. Eventually, the least expected, COVID-19 manifested itself calmly in the city of Wuhan, and not even the brightest of economists (Eichengreen 2020) could envisage its impact to be as heavily widespread, particularly to the destruct of the world economy as empirically documented in a Structural Vector Autoregression (SVAR) study carried out with reference to the Baltic area (Yilmazkuday 2020).

With reference to Gschwandtner's (2009) crafted usage of the term Shrinkonomics, the emergence of COVID-19 indeed manifested itself with its impact adversely felt in all sectors of the world economy - epitomized through high risk of population mortality, downsizing of economic activities, and the return of draconian-like measures involving forced quarantine in a bid to stampede governments' authority of addressing critical issues at hand. On a parallel note, central banks across the world had no option but to exercise their mandates (notably, price and financial stability) to act swiftly on policy measures relating to: "quantitative easing 
to address possible financial instability in the system (an approach highly utilised in the 2007-09 global financial crash - see Kapetanios et al. 2012), adjusting Monetary Policy Rate (MPR) and other forms of incentivization." This could be interpreted as a way of the cushioning distressed state of households, businesses, and economic agents' uncertainties about events in individual domestic economy activities and eventual spillovers in the international community.

This is now seen as the most topical of threat to globalization, particularly in terms of the negative impact on value-chain network (China is estimated to account higher percentage of global supply and demand - Yilmazkuday 2020), and also the need for people to be self-quarantined and at the same time observe social distancing in a bid to prevent wide-scale spread of COVID-19 (French and Monahan 2020). Worries about the continued spread of the pandemic are still a concern for people - a manifestation of God's test of human resilience to address vulnerability in the area of natural health calamity in the world economy. Stock market volatility around the world signalled turbulence - epistemologically construed as a form of neglect on the part of capitalists given the high risk of escalation when one considers the fact that COVID-19 was recently ranked tenth position in the 2020 Global Risk Report (World Economic Forum 2020; Ramelli and Wagner 2020).

Despite the direct impact on health and psychological outcome saturating in the minds of people, there is, most importantly, a glare of economic ramification felt as witnessed in the assessment of stock market negative reaction, where China is mentioned in firm's disclosure pertaining to international activities (Ramelli and Wagner 2020). It was clearly seen that the reaction of such outcomes manifested poor performance with value-chain activities as participants' expectations started to signal uncertainty. This was mainly as a result of the uncontrolled spread of the outbreak, which in a way can be construed as wreckage on capitalists' direction of globalization, given their inherent tendency of tilting attention towards the accumulation of profits, to the demise of building communities through high-end investment in Research and Development (R\&D). COVID-19 has witnessed the breakdown of essential structures, through collapse of institutional capabilities to address risks from the early signs of an outbreak, which is now seen to be taking a toll on seamless damages to the world economy. As stressed by Baldwin and di Mauro (2020: 14), the expectation of a recession can only be made to flatten out through preventive policies that incorporate all, but not limited to the highlighted measures - monetary, financial regulation, social insurance, and bumping up industrial and trade arrangements.

\section{Emerging Innovative Interventions on Globalization Approach to Addressing Health Pandemic}

The revelation of COVID-19 pandemic across continental borders is a real challenge in understanding how far human ingenuity will go in withstanding the full extent of natural calamity, more so in attesting to the fact that more is needed in the area of Research and Development (R\&D) to sustain the global economy from the continuous threat of health and economic instability. The test of COVID-19 should be considered as a wake-up call for human intervention to probe further into the unknown ontology of their creative mind-set, to address what is now considered the biggest challenge of human sustained existence in the world.

The craft-mindedness of fiscal and economic policies seems to have been exhausted and - as explained by Eichengreen (2020) - cuts associated with almost Zero MPR and other rates and also taxes as announced around the world economy are indeed welcoming steps in calming stock market negative signals about the impact of COVID-19. In fact, escalation of the virus in nearly all areas of the world economy have seen businesses hedging high risks by selling bonds amidst massive decline in share prices, while central banks also reciprocated by buying toxic assets in a bid to restore confidence in the world economy (Markus 2020). 
The world economy is at a high risk of being plunged into recession, and even with the effort of central banks to utilize legal mandates (price and financial stability) to calm situations, there are high chances of a recession reaction, which will be most highly felt by smaller economies and the business community in the months and years ahead. It is very necessary that actions are taken now, through emerging innovations in support of globalization effort that economies around the world have enjoyed, through creative and dynamic intervention in innovative technologies since the 1990s (Jackson 2020a, in press-b; Estrada and Arturo 2020).

As a prescription to the aforementioned points regarding creative innovation, the global economy should act in the area of redefining the parameters of financial innovation strategies that are geared towards mitigating risks associated with health pandemic, namely, COVID-19, which is almost at the point of creating lasting damage to the world economy. In view of the World Economic Forum's (WEF - 2020) ranking report on health risk to global economic stability, financial institutions should bolster R\&D effort in addressing specific risks to globalization and the overall impact on value-chain processes of mobility associated with businesses and human beings. As witnessed from the Wuhan COVID-19 spillover, financial institutions, particularly in developed economies, should commence serious innovation plans with capitalists or businesses by spelling out possible creative modalities for hedging risks connected with their (international) operations in countries perceived as highly vulnerable to health calamity.

Despite China's progress in terms of moving into the international band of emerging economies, epitomized by its high growth rate immediately after the USA, COVID-19 was still not considered as the most thought-about pandemic, until reaction of stock market started manifesting signal of uncertainties through dip-cut in index figures (Ramelli and Wagner 2020). While capitalists in western developed economies relaxed at the onset, with the perception that COVID-19 is just a problem with China, the influence of globalization (induced through free movement of people across international borders) was still making it possible for every area of the world to be exposed to such vulnerability as now seen with lockdown of businesses and self-quarantining, witnessed almost everywhere in the world economy (Gross 2020).

Equally as in the case of addressing innovation in the financial system, the best way forward in calming fears about the continuous risk to health pandemic is for resources to be diverted (by both governments and businesses) into the expansion of R\&D laboratories (associated with SDG9). Despite the effort of economies/central banks and philanthropists to intervene in providing economic and financial support announced in the form of drastic cut in rates (MPRs and taxes), the real answer in bringing calmness to the continued risk of world recession is to broaden industrial base, through support for creativity in science and technology, with particular focus on health and well-being (reference to SDG3). In this vein, there is a need to make sure Science, Technology, Engineering and Mathematics (STEM) are integral part of governments' agenda across the world (Jackson and Jackson 2020; TechnWomen 2019; Jamme 2015), more so in the area of pursued effort in finding lasting solution to airborne and other form of contagious diseases.

On the above note, funding for high level R\&D in universities and specialist laboratories must be made an integral part of government expenditures. This will make it possible for the effort of globalization to be viewed as a worthwhile venture for capitalists, whose intention is to maximize profits through transfer of technologies in regions with cheaper cost of production utilities. The escalation of COVID-19 pandemic also brings one to think strongly in the direction of theoretical critiques levied on the motive for globalization, which as seen here seems to be manifesting itself on the angle of selfishness. This could be construed as a deliberate attempt for capitalists to amassing profits, while ignoring the social and economic ramifications of their delayed actions on related incidence connected with global pandemic. To some extent, outcomes from COVID-19 have pointed in the direction of a rethink of globalization, given the delayed reaction of capitalists 
lagged reaction to intervene earlier, which is now costing the world economy, with signs of a possible global recession.

The effort of capitalists and politics towards championing globalization needs to be reconsidered given the experiences from COVID19. Globalization is very highly favored, but not to the extent of skewing effort away from capacitating domestic investments in support of human creativity. Economies around the world and particularly capitalist economies must reconsider their focus towards inward approach, in support of an expansion in Small and Medium Enterprises (SMEs) operations, which are really needed to bolster risks of a recession looming. In this vein, support that results in the expansion of creativity connected with SMEs must be encouraged, possibly through funding for entrepreneurship in universities and the creation of specialist institutions. Despite the tendency of global market intervention to be skewed in the direction of creative destruction in technology innovation (Jackson 2020a), economies must endeavor to intervene in promoting SMEs creativity towards high-end productivity in essential commodities, which are geared towards sustaining human well-being during time of distress, as witnessed with COVID-19. Even though the world is diverting attention from the approach of Import Substitution Industrialization Jackson and Jabbie (2019), experiences from COVID-19 have made it more important for economies to consider adopting protectionist policies as a way of building resilience against the possible collapse of local economies - this will make it conceivable to protect jobs and institutions from destruction.

\section{Embracement of the SDG's with the Incidence of COVID-19}

The real test of embracing all SDGs has manifested itself as the impact of COVID-19 unfolds across the world economy. On this note, one will be very much inclined to argue in favor of some of the theoretical critiques levied (PooJo Online), more so in relation to the direction of globalization. In view of this, the eclectic theory of globalization speaks more in the direction of embracing all 17 SDGs, given its postmodern focus in critiquing anything that is contrary to addressing balances in human intervention towards building a cohesive society. There is a high risk at play here for a delayed action in achieving the SDGs given the present danger of COVID-19's impact on the world economy - such impacts have been manifested through depressed state of economies and the continued uncertainty of recession looming, despite efforts made by central banks to allay fears through an almost zero interest rate announced in many of the developed economies (notably, the UK and the USA) and the ramping up of quantitative easing to cushion damages to institutions and stabilizing the financial system.

Even though the effort of central banks and governments across the world economy seem to be speaking in one language, which is to address issues revolving around the curtailment of poverty and hunger and protecting health and well-being (SDG1, 2, and 3) through interventions in slashing rates (MRP and Taxes), there is still the need for economies to focus attention inwardly as a way of protecting lives and institutions from collapsing. Experience from COVID-19 seems to manifest itself well in the direction of unearthing the selfish nature of capitalists' focus towards a singular objective, which is to increase profits for shareholders. In reality, such selfish approach is paying dividend in the direction of zero-earned profits, and with the chances of recession looming, there is a risk of indebtedness on the part of households and businesses - this in many cases will continue to be a burden on central banks' balance sheet and governments through innovative tax policies as a way of cushioning distress to economic agents across the board. By the looks of it, there is expectation that impact of COVID-19 will continue to manifest itself through sluggish growth rate in years to come (Baldwin and di Mauro 2020), even with the effort of addressing concerns around the improvement of $\mathrm{R} \& \mathrm{D}$, pertaining to health and well-being (SDG3).

The revelation of COVID-19 really speaks to the fact that more is needed in the direction of bolstering investments to capacitate the human creative minds (Jackson et al. 2020). Initiative towards creative investment is an integral part of 
the successful achievement of the 2030 SDG goals, which means that human ingenuity will need to be explored through different ways but with high focus in the direction of science and technology. Health pandemics, particularly airborne diseases, are proving to be the most considered challenge to human existence and the stability of the world economy. Hence, R\&D should be made the focal point of governments' agenda in a bid to ensuring their effort towards the 2030 SDG goal is achieved. Such approach must be practically focused in creating job opportunities, with its ultimate impact manifested in high potential for economic growth and development (SDG8), while at the same time building capacity for the expansion of technology-based infrastructures (SDG9), geared towards utilizing human ingenuity in a productive and equitable way. Such approach should incorporate gender equality as an integral part of the agenda to capacitate human ingenuity (reference to SDG5 and $10-$ reference to Cho 2013). To strengthen such effort, international institutions such as the World Trade Organization (WTO), the United Nations (UN), World Health Organization (WHO), the World Bank (WB), and many more should endeavor to synchronize their effort (ensuring legal agreements are well in place to protect smaller economies) to make sure all the SDGs (particularly SDG 16 and 17) are achieved, despite continued risks to the stability of the global economy.

\section{Conclusion and Recommended Points for Championing New Thoughts on Creative Innovation}

The agenda of political and liberalist approach on globalization, geared towards mobilizing industrial capacity from high- to low-cost regions as a way of increasing profits, must be revisited. The real test of such imbalanced approach has manifested itself through the incidence of COVID-19 and for which the impact will be a talked about agenda for years to come. As explained by Hutton (8th March, 2020) in The Guardian newspaper article, coronavirus will not bring an end to globalization but will change it hugely for the better. The approach to its governance is very critical on how best the world is to be seen as a unified force - the mandate of international institutions like the World Health Organization (WHO) should make it possible for governments across the globe to pull resources, supposedly geared towards fighting the spread of COVID-19 and many more related illnesses; such may also be the case with parallel move on concerns pertaining to climate change, the ocean, finance, and cybersecurity, which are critical for the achievement of SDG in the year 2030 (Hutton 2020).

Government intervention that seeks to address market imperfection (Jackson and Jabbie 2019) is quite essential here, particularly in ensuring real investment in human capital is geared towards exploring innovative ways of improving and stabilizing the world economy. Effort in building a cohesive world economy is highly under the control of governments and international organizations like the UN and World Bank to make sure fair game is at play, where institutions are seen to be working on the interest of building a cohesive society as opposed to amassing profits, which, as seen in the case with the initial neglect for COVID-19, ended up as zero outcome for investors as manifested in stock market news around the world (Ramelli and Wagner 2020).

As already highlighted, businesses and governments should endeavor to focus their attention towards high-end investments in R\&D that support creativity in science and technology - such approach will advertently support the SDG3 agenda on Good Health and Well-Being. The experiences of COVID-19 have seen how relevant it is for economies to promote healthy living, particularly the eradication of airborne diseases that can be easily spread by way of the liberalist approach of globalization. The lesson from COVID-19 indicates that Health Economic Science is as equally important as the management of traditional economic policies pursued in institutions like central bank.

Central banks across the globe were very quick to respond through inducement of packages to calm global panic about the perceived downward trend in economic activities, but the reality still 
speaks to the need for increased R\&D investment, particularly in the curing of health-related illnesses to calm investors' worry about risks to the sustainability of their investments and, also, the sustenance of households' livelihoods in general. Equally, there is also a responsibility on the part of governments worldwide to act swiftly by instituting policies to bolster investment in human creativity - this will allay uncertainties about the possible spread of COVID-19 and other related airborne diseases.

In conclusion, the world economy and, more so, governments all around must continue their deliberations to providing much needed support in the area of $R \& D$ to enhance creativity in health research, while at the same time affirming their commitment towards achieving the SDGs by the target year of 2030 - now considered the greatest challenge for the world economy, given the tight fiscal environment economies are now placed in amidst the emergence of COVID-19. The emphasis here should be towards the enhancement of ethical investments, particularly that which is focused in promoting healthy living and sustained well-being for citizens in the global community this should take precedence over all other forms of injudicious creativity connected with the development of destructive technologies (notably, nuclear armaments), which have proved more catastrophic to health (6 August 1945, atomic bomb attach in Hiroshima as a cited example of memory complex incidence - Olesen 2019), with the possibility of alluring the persistent uncertainties on stock market reactions across the globe. In view of Schumpeter's approach to entrepreneurship, resources should be skewed in the direction of investing on human creativity (Jackson 2020a), with the ultimate goal of ensuring that the calamity of COVID-19 and other related diseases will ultimately be seen as less threatening to human existence on this earthly ecosphere.

\section{Cross-References}

\footnotetext{
- Globalization

> Industrialization

$>$ Innovation
}

- Market Development

- Research and Development

\section{References}

Baldwin R, di Mauro BW (2020) Introduction. In: Mitigating the COVID-19 economic crisis: act fast and do whatever it takes. Centre for Economic Policy Research (CEPR) Press, London

Bassino JP, Williams JG (2017) From commodity booms to economic miracles: why southeast Asian industry lagged behind. In: O'Rourke KH, Williams JG (eds) The spread of modern industry to the periphery since 1871. Oxford University Press, Oxford

Chatterjee I (2019) Radical globalization. Keywords in radical geography: antipode at 50. https://doi.org/ 10.1002/9781119558071.ch43

Cho S-Y (2013) Integrating equality: globalization, women's rights, and human trafficking. Int Stud Q 57(2013):683697. https://doi.org/10.1111/isqu.12056

Clayton T (2020) Coronavirus impact study: CEBR forecasts worst peace-time global recession since the 1930s. Centre for Economic Research (CEBR). https: //www.exchangerates.org.uk/news/28995/2020-03-23coronavirus-impact-study-cebr-forecasts-worst-peacetime-global-recession-since-the-1930s.html. Accessed 23 Mar 2020

Danaeefard H, Abbasi T (2011) Globalization and global innovation. In: Pachura P (ed) The systemic dimension of globalization, Intech Open. https://doi.org/10.5772/ 17282

Dreher A (2006) Does globalization affect growth? Empirical evidence from a new index. Appl Econ 3 (10):1091-1110

Eichengreen B (2020) The Human Capital Costs of the Crisis. Available at: https://www.project-syndicate.org/ commentary/covid19-pandemic-erosion-ofhuman-capi tal-by-barry-eichengreen-2020-04. (Accessed: 15 Apr 2020).

Estrada R, Arturo M (2020) Is globalization responsible of the Wuhan-COVID-19 worldwide crisis. https://doi. org/10.2139/ssrn.3551944

French M, Monahan T (2020) Dis-ease surveillance: how might surveillance studies address COVID-19. Surveill Soc 18(1):1-11. https://doi.org/10.24908/ss.v18i1.13985

Griffith LM, Marion JS (2020) Globalization. In: Brown N, McIlwraith T, de Gonzalez T (eds) Perspectives: an open introduction to cultural anthropology, 2nd edn. The American Anthropological Association, United States of America

Gross M (2020) Virus outbreak crosses boundaries. Curr Biol 30(5):R191-R194. https://doi.org/10.1016/j.cub. 2020.02.049

Gschwandtner G (2009) SHRINKONOMICS - how should we adjust to the incredibly shrinking economy? https://blog.sellingpower.com/gg/2009/07/shrinkonom 
ics-how-should-we-adjust-to-the-incredibly-shrinkingeconomy.html. Accessed 16 Mar 2020

Held D, McGrew AG (2007) Globalization theory: approaches and controversies. Can J Polit Sci 41 (3):796-797. https://doi.org/10.1017/S000842390808 0967

Hutton W (2020) Coronavirus won't end globalisation, but change it hugely for the better. https://www.google.co.uk/ amp/s/amp.theguardian.com/commentisfree/2020/mar/ 08/the-coronavirus-outbreak-shows-us-that-no $=$ one-cantake-on-this-enemy-alone. Accessed 10 Mar 2020

Jackson EA (2016) Ontological and epistemological discourse(s) on sustainable development: perspective on Sierra Leone in the aftermath of a decade of civil unrest. Manag Sustain Dev 8(1):35-43

Jackson, E.A. (2020a). Fostering sustainable innovation through creative destruction theory, in: Leal Filho W., Azul A., Brandli L., Özuyar P., Ozuyar, P.G. (ed.) Industry, innovation and infrastructure. Encyclopedia of the UN sustainable development goals. Springer, Cham.

Jackson EA. (2020b) Economics of technology innovation for sustainable growth - with reference to Sub-Saharan Africa (SSA). In: Leal Filho W, Azul A, Brandli L, Özuyar P, Ozuyar PG (eds) Industry, innovation and infrastructure. Encyclopedia of the UN sustainable development goals. Springer, Cham

Jackson EA, Jabbie M (2019) Understanding market failure in the developing country. Context (online first). In: Walter LF (eds) Decent work and economic growth: encyclopedia of sustainable development goals. Springer Nature Publisher, Cham. https://doi.org/ 10.1007/978-3-319-71058-7_44-1

Jackson EA, Jabbie M (2020) Twin Deficits hypothesis as an indication of government failure in Sierra Leone: An empirical investigation (1980-2018), J Econ Pol Res 7 (1):43-68. https://doi.org/10.266R658440. Istanbul

Jackson EA, Jackson HF (2017) The role of corporate social responsibility in improving firms' business in the direction of sustainable development, accountability and transparency. African J Econ Sustain Dev 6(2/ 3):105-118. https://doi.org/10.1504/AJESD.2017. 089942

Jackson EA, Jackson J (2020) Global perspectives on gender sensitivity and economic benefits. In: Walters L, Filho et al (eds) Gender equality: encyclopedia of sustainable development goal. Springer Nature Publisher, Cham

Jackson EA, Jackson EES, Jackson HF (2020) Nurturing career development for human resource sustainable development. In: Leal FW, Azul A, Brandli L, Özuyar $\mathrm{P}$, Wall T (eds) Decent work and economic growth. Encyclopedia of the UN sustainable development goals. Springer, Cham. https://doi.org/10.1007/978-3319-71058-7 2-1

Jamme ME (2015) What STEM can do for Africa? https:// www.weforum.org/agenda/2015/01/what-stem-can-dofor-africa/. Accessed 11 Mar 2020
Kapetanios G, Mumtaz H, Stevens I, Theodoridis K (2012) Assessing the economy-wide effects of quantitative easing. Econ J 122(564):F316-F347

Kidman G, Chang CH (2020) What does "crisis" education look like? Int Res Geograph Environ Educ 29(2):107111. https://doi.org/10.1038/2046.2020.1730095

Kinnvall C (2004) Globalization, identity, and the search for chosen traumas. In: Hoover KR (eds) The future of identity: centennial reflections on the legacy of Erik Erikson. Lexington Books, pp 111-136

Leach M (2020) Echoes of Ebola: social and political warnings for the COVID-19 response in African settings. https://somatosphere.net/forumpost/echoes-ofebola/. Accessed 21 Mar 2020

Markus E (2020) EUR/USD, GBP hedging perspectives. ECR Research. https://www.ecrresearch.com/system/ files/reports/200317-EURUSD\%20\%20GBP\%20Hedg ing-en_0.pdf. Accessed 18 Mar 2020

Milberg W, Winkler D (2013) Outsourcing economics. Cambridge University Press, Cambridge

Mozaffari M (2002) A world-constructivist approach. In: Globalization and civilization. Psychology Press (Ebook)

Murat A, Isaac OM (2019) Effects of globalization on the performance of small and medium scale Enterprises in Nigeria. Am J Environ Resour Econ 4(4):125-131. https://doi.org/10.11648/j.ajere.20190404.12

O'Rourke KH (2018) Two great trade collapses: the interwar period and great recession compared. IMF Econ Rev 66(3):418-439

O'Rourke KH (2019) Economic history and contemporary changes to globalization. J Econ History 79(2):356382. https://doi.org/10.1017/S0022050719000044

O'Rourke KH, Williams JG (2000) When did globalization begin? NBER working papers no. 7632. National Bureau of Economic Research

O'Rourke KH, Williams JG (2017) The spread of modern industry to the periphery since 1871 . Oxford University Press, Oxford

Olesen T (2019) The Hiroshima memory complex. Br J Sociol 71(1):81-95. https://doi.org/10.1111/14684446.12717

Ougaard M (2004) Introduction. In: Political globalization. International political economy series. Palgrave Macmillan, London. https://doi.org/10.1057/9781403943996_1

Overland I (2016) The missing link in globalization. Energy Res Soc Sci 14:122. https://doi.org/10.1016/j. erss.2016.01.009

Perraton J (2019) Globalization after the financial crisis: structural change and emerging market multinationals. In: Breinbauer A, Brennan L, Jager J, Nachbagauer A, Nolke A (eds) Emerging market multinationals and Europe. Springer, Cham

PooJo (Online) Eight theories of globalization explained. http:/www.politicalsciencenotes.com/articles/8-theoriesof-globalization-explained/642. Accessed 17 Mar 2020

Ramelli S, Wagner A (2020) What the stock market tells us about the consequences of COVID-19? In: Baldwin R, di Mauro BW (eds) Mitigating the COVID-19 
economic crisis: act fast and do whatever it takes. Centre for Economic Policy Research (CEPR) Press, London

Rowe DM (2005) The tragedy of liberalism: how globalization caused the first world war. Secur Stud 14 (3):407-447. https://doi.org/10.1080/096364105 00323153

Saffa M, Jabbie M (2020) Developing transformational competencies for sustainable development. In: Leal FW, Azul A, Brandli L, Özuyar P, Wall T (eds) Quality education. Encyclopedia of the UN sustainable development goals. Springer, Cham. https://doi.org/10.1007/ 978-3-319-69902-8_116-1

Shangquan G (2000) Economic globalization: trends, risks and risk prevention. CDP background paper no. $1 \mathrm{ST} /$ ESA/2000/CDP/1. https://www.un.org/en/develop ment/desa/policy/cdp/cdp_background_papers/ bp2000_1.pdf. Accessed 18 Mar 2020

TechWomen (2019, March 19) Sierra Leone day 2: showing students a future in stem. https://www.techwomen.org/ uncategorized/sierra-leone-day-2-showing-students-afuture-in-stem. Accessed 10 Mar 2020

Vujakovic P (2010) How to measure globalization? A new globalization index (NGI). Atl Econ J 38(2):237. https://doi.org/10.1007/s11293-010-9217-3

Warburton CES, Jackson EA (2020) Monetary policy responses to exogenous perturbations: the case of a small open economy (2007-2019). PSL Q Rev 73(292)

Wivel A (2004) The power politics of peace exploring the link between globalization and European integration from a realist perspective. Coop Confl 39(1):5-15. https://doi.org/10.1177/0010836704041104

World Economic Forum (2020) The global risk report 2020. http://www3.weforum.org/docs/WEF_Global_ Risk_Report_2020.pdf. Accessed 24 Mar 2020

World Health Organization (Online) Globalization. https:// www.who.int/topics/globalization/en/. Accessed 17 Mar 2020

Yilmazkuday H (2020) Coronavirus disease and the global economy. SSRN 3554381. https://doi.org/10.2139/ Ssrn.3554381 